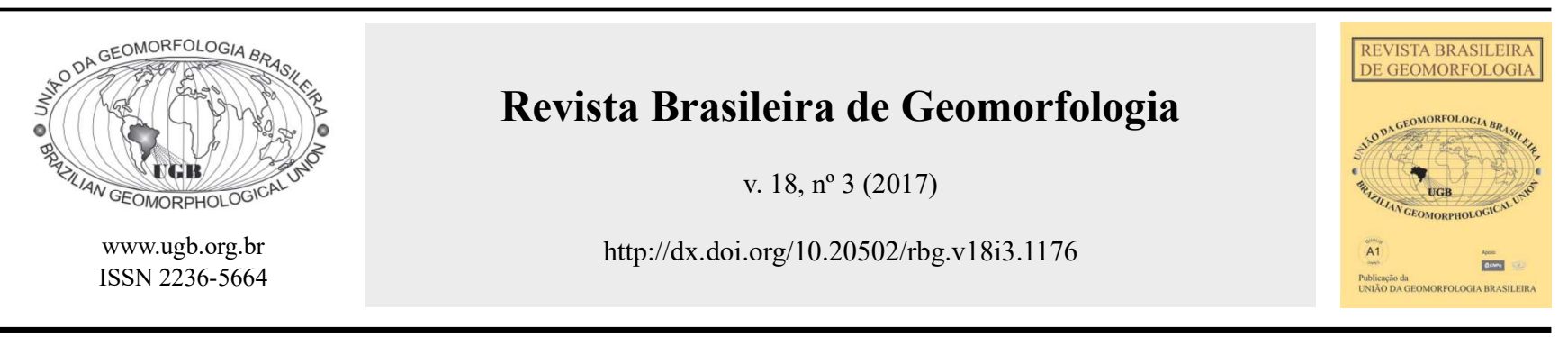

\title{
METODOLOGIAS DE AVALIAÇÃO DO PATRIMÔNIO GEOMORFOLÓGICO COM VISTAS AO SEU APROVEITAMENTO GEOTURÍSTICO - UM ESTUDO APLICADO ÀS QUEDAS D'ÁGUA DO MUNICÍPIO DE INDIANÓPOLIS (MINAS GERAIS - BRASIL)
}

\author{
METHODOLOGIES FOR THE ASSESSMENT OF \\ GEOMORPHOLOGICAL HERITAGE AIMING AT ITS USE IN \\ GEOTURISM-A STUDY APPLIED AT THE WATERFALLS IN THE TOWN \\ OF INDIANÓPOLIS (MINAS GERAIS - BRAZIL)
}

Lilian Carla Moreira Bento

Instituto de Geografia, Universidade Federal de Uberlândia Av. João Naves de Avila, 2121, Uberlândia, Minas Gerais. CEP: 38400-902. Brasil Email:liliancmb@ufu.br

Adriana Lacerda de Brito Instituto de Geografia, Universidade Federal de Uberlândia Av. João Naves de Ávila, 2121, Uberlândia, Minas Gerais. CEP: 38400-902. Brasil Email: alacerdab@hotmail.com

Emmeline Aparecida Silva Severino Instituto de Geografia, Universidade Federal de Uberlândia Av. João Naves de Ávila, 2121, Uberlândia, Minas Gerais. CEP: 38400-902. Brasil Email: emmelineseverino@yahoo.com.br

Isley Borges da Silva Junior Instituto de Geografia, Universidade Federal de Uberlândia Av. João Naves de Ávila, 2121, Uberlândia, Minas Gerais. CEP: 38400-902. Brasil Email: isleyborges@hotmail.com

Roberta Lisboa Instituto de Geografia, Universidade Federal de Uberlândia Av. João Naves de Ávila, 2121, Uberlândia, Minas Gerais. CEP: 38400-902. Brasil Email: robertalisboa08@hotmail.com

Virgínia Corrêa Santos de Andrade Instituto de Geografia, Universidade Federal de Uberlândia Av. João Naves de Ávila, 2121, Uberlândia, Minas Gerais. CEP: 38400-902. Brasil 
Informações sobre o Artigo

Recebido (Received):

18/03/2017

Aceito (Accepted):

$01 / 06 / 2017$

\section{Palavras-chave:}

Geodiversidade; Turismo;

Conservação.

\section{Keywords:}

Geodiversity; Tourism;

Conservation.

\section{Resumo:}

A elaboração de metodologias de avaliação do patrimônio geomorfológico com vistas ao aproveitamento pelo geoturismo é uma tendência contemporânea que viabiliza o resgate da objetividade para a conservação de aspectos abióticos do local, bem como da valorização dos pressupostos definidos a partir da paisagem estética cultural, da educação e da ciência da qual esta temática emerge. Este estudo, aplicado às quedas d'águas do município de Indianópolis, articula esses preceitos à noção de potencial turístico revelado pelo lugar com vistas para o aproveitamento decorrente desta atividade. Para isso foi realizada uma análise qualitativa com base nos critérios que contemplam a categoria de quedas d'água e uma avaliação quantitativa em campo, privilegiando os aspectos enquanto potenciais turísticos e científicos em consonância com as formas analisadas em seus respectivos locais de origem. Trata-se, assim, de buscar alternativas

metodológicas de avaliação que embasem as pesquisas no âmbito da geodiversidade e da geoconservação sob uma perspectiva que se integra ao propósito de conservação do meio ambiente, ao mesmo tempo em que se alia a atividade do geoturismo.

\begin{abstract}
:
The elaboration of methodologies for the assessment of geomorphological heritage aiming at its use in geotourism is a contemporary trend that enables the rescue of objectivity for the conservation of the site's abiotic aspects, as well as of the appreciation of assumptions defined based on the cultural aesthetic landscape, education and science. The present study, applied to the waterfalls in the town of Indianópolis, relates precepts of the notion of the site's tourism potential for its establishment as geotourism. For that, a qualitative analysis was carried out based on the criteria that apply to the waterfall category, as well as a field quantitative assessment, focusing on the potential tourism and scientific aspects in line with the forms analyzed in their respective places of origin. It is then an attempt to search for alternative assessment methodologies to base research in the scope of geodiversity and geo conservation integrating the purpose of environmental preservation and geotourism activities.
\end{abstract}

\section{Introdução}

A pesquisa aplicada ao geopatrimônio e, nesse estudo, especificamente à categoria do patrimônio geomorfológico, permite ampliar o conhecimento e a compreensão não só da composição que reveste a superfície da Terra em sua dinâmica com o meio, mas sua evolução ao longo do tempo geológico. Ela se define a partir das interações que se configuram entre os aspectos bióticos e abióticos de uma dada especificidade local. Observa-se, recentemente, a necessidade do uso de metodologias que contemplem o significativo papel do geopatrimônio em áreas de potencial turístico, cuja necessidade é decorrente da ausência de pesquisas aplicadas ao planejamento sob uma perspectiva de valorização dos aspectos geológicos, geomorfológicos, do solo, dentre outros elementos abióticos. Tudo isso de maneira que eles possam contribuir, através da coleta e da análise de dados, para a elaboração de procedimentos de manejo e de tomadas de decisão embasadas nos conceitos de Geodiversidade e de Geoconservação.

O conceito de Geodiversidade emerge a partir da década de 1990 e, em linhas gerais, refere-se a todos os elementos naturais de base abiótica, bem como aos processos, pretéritos e atuais, que os deram origem, tais como os minerais, rochas, solo, relevo, fósseis, entre outros (Gray, 2005; Brilha, 2005; Nascimento, Ruchkys e Mantesso Neto, 2008). A disseminação deste conceito se pauta na necessidade de uma reflexão ampla sobre as atividades humanas e as ameaças exploratórias, bem como nas possíveis alternativas a essas ameaças tão constantes a geodiversidade. 
Por ser definido enquanto um "pedaço" da Geodiversidade, o Geopatrimônio ou Patrimônio Geológico, e sua legitimação enquanto tal, decorre da identificação dos Geossítios da qual o Patrimônio Geológico se constitui, tendo como valores intrínsecos a cultura, o estético, o econômico, o científico, o educativo e o turístico (Gray, 2004; Silva et al., 2009). O conceito de Patrimônio Geológico vem sendo difundido em todo o mundo nas últimas décadas em função da emergência da conservação e divulgação dessa vertente abiótica da natureza, e, mais recentemente, na implementação dos Geoparques (Brilha, 2005; Araújo, 2005; Borba, 2011; Schobbenhaus; Silva, 2012). Relevante destacar que o Geopatrimônio é uma categoria temática dentro do contexto amplo do Patrimônio Paisagístico e pode ser considerado um conceito guarda-chuva que engloba como patrimônio todos os elementos abióticos da natureza dotados de algum tipo de valor (Figura 1). No caso do Patrimônio Geomorfológico, ele é constituído pelo conjunto de formas de relevo, solos e depósitos correlativos que apresentam evidente valor científico e raridade e/ou originalidade (Pereira, 1995; Vieira, Cunha, 2004), ou seja, esse termo comporta todas as formas paisagísticas que se sobressaem entre os vestígios geológicos existentes, como geoformas de origem fluvial, as quedas d'água (Evangelista; Panisset, 2014).

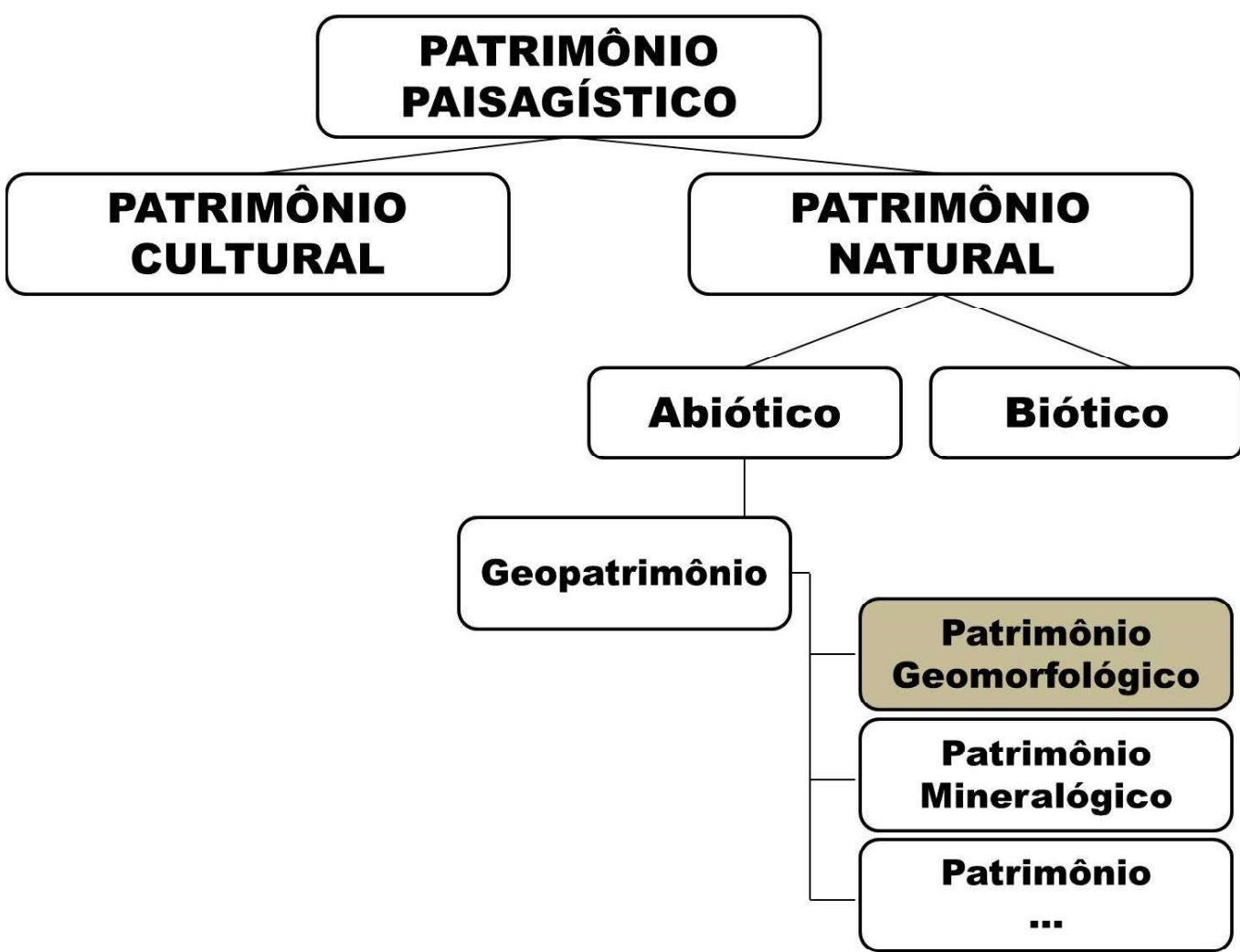

Figura 1 - Fluxograma com o enquadramento do Patrimônio Geomorfológico

Fonte: Adaptado de Pereira, et al., 2004, p.2.

A partir da declaração dos Direitos à Memória da Terra, em 1991, a noção de Patrimônio associa-se ao complemento Natural considerando não apenas a relevância da conservação dos aspectos biológicos, mas também dos aspectos geológicos de onde eles se constituem. Dadas às particularidades que o compõe, e para além da biodiversidade, o Patrimônio Natural se corporifica a noção de Geodiversidade na medida em que os estudos deste segmento verificam a importância deste aspecto na significação do todo que representa a paisagem do lugar. O prefixo Geo, portanto, abraça a importância da significação do meio abiótico em conceitos estruturantes de caráter científico e atividades econômicas relacionadas com esta natureza. Nesta mesma perspectiva, sustenta-se a importância da Geoconservação que "[...] tem como objetivo a caracterização, conservação e gestão do patrimônio geológico e processos naturais associados" (Brilha, 2005, p. 53). 
Uma das ferramentas da Geoconservação, se for bem planejado, é o Geoturismo. Nova prática turística que se destaca pelo trânsito e a presença coletiva que compreende e torna passível de valorização uma área, sobretudo quando compreendidas as possibilidades de desenvolvimento econômico circundante. Por outro lado, o potencial estético e cultural, característicos da superfície do relevo que se evidencia, remete a importância da apreciação dos valores e das diferenças mais significativas da qual estas composições pertencem. Destacam-se entre as formações atribuições culturais, composições minerais, formas diferenciadas do relevo, paisagens estéticas e apreciações arqueológicas.

De acordo com Bento (2010) o Geoturismo surgiu nos países desenvolvidos, alastrando-se atualmente para outras partes do mundo. Por esse motivo, grande parte de referências relacionadas a esse segmento turístico está em língua estrangeira. De certo, a relevância do Geoturismo ainda se faz crescer no Brasil, embora esteja se tornando cada vez mais uma contribuição indispensável em áreas cuja relação potencial turístico e meio abiótico de um dado lugar se faça dinamizar e investir. Ainda que anteposto ao turismo rural ou ao ecoturismo, o Geoturismo surge como atividade que não exclui as diferentes potencialidades implícitas no lugar (Dowling, 2001; Robinson, 1998; Reynard, 2008; Gray, 2011), mas, pelo contrário, solicita uma análise dessas potencialidades em sua base de formação, sua superfície e composição.

Nas últimas décadas tem se avolumado o número de pesquisas voltadas a avaliação do Geopatrimônio. Inicialmente, essas pesquisas eram de cunho mais teórico e, atualmente, é evidente um esforço para reduzir a subjetividade desse tipo de análise, agregando um viés numérico a partir, principalmente, de algumas variáveis relacionadas aos valores desse tipo de patrimônio, bem como ligadas ao seu uso e proteção (Lima, 2008; Pereira, 2006; Bento e Rodrigues, 2014). Esse tipo de estudo é uma ferramenta indispensável no processo de Geoconservação, uma vez que possibilita identificar as potencialidades e fragilidades do Geopatrimônio, apontando para os locais que demandam maiores esforços de conservação ou divulgação (Brilha, 2002; Gray, 2005; Pereira, 2006; Forte, 2008; Rodrigues, 2008; Fonseca, 2010; Pinto, Travassos, 2013).

Já existem alguns estudos que abordam, notadamente, metodologias de avaliação quantitativa do potencial geoturístico de quedas d'água, entre eles, Santos
(2015) faz a caracterização geoambiental para avaliar o potencial geoturístico das cachoeiras do município de Garulhos (São Paulo), destacando as condições de acesso, avaliação da trilha, aspectos do local (infraestrutura) e atividades possíveis. Santos, Mariano e Nascimento (2015) avaliaram o potencial geoturístico das quedas d'água do município de Bonito (Pernambuco), porém, evidenciando as cachoeiras em rochas ígneas e metamórficas através da análise do Valor Intrínseco, Uso potencial e Necessidade de proteção. E, por fim, Luz Netto (2015) avalia as quedas d'água da Bacia Hidrográfica do Rio Claro (Minas Gerais), analisando os critérios de Valor Científico, Estético e Turismo, bem como a necessidade de proteção e, acrescenta outra variável na avaliação, que é a geomorfometria da bacia. Esses estudos tiveram o objetivo de avaliar as quedas d'água enquanto Patrimônio Geomorfológico e as metodologias empregadas variam, mas existe um encaminhamento comum que é a consideração dos valores associados à Geodiversidade e a consideração de aspectos relacionados ao uso e proteção desses locais. Para cada contexto geográfico e objetivo específico são acrescidos novas abordagens, as quais acabam por evidenciar um avanço e apropriação da temática por áreas distintas, como a Geologia e Geografia, principalmente.

Caminhando nessa nova perspectiva, o trabalho em questão objetivou analisar qualitativa e quantitativamente o potencial geoturístico de Indianópolis, região do Triângulo Mineiro, através das quedas d'água, atrativos para aos visitantes, uma vez que essa prática turística coloca em evidência aspectos relacionados ao meio abiótico como legado científico e educativo, estético e cultural de um lugar. Além disso, esse objetivo carrega em seu seio a expectativa de que tal estudo possa balizar a gestão territorial do município, contribuindo para a proteção desses espaços que já são visitados e passam, na maioria das vezes, por processos de degradação, carecendo de instrumentos que direcionem para a criação de medidas de conservação e divulgação.

\section{Metodologia}

Indianópolis (Figura 2) está localizada no Triângulo Mineiro, no estado de Minas Gerais, Brasil, entre as coordenadas geográficas $18^{\circ} 51^{\prime} 06^{\prime \prime}$ e $19^{\circ} 07^{\prime} 13^{\prime \prime}$ de latitude Sul e $47^{\circ} 39^{\prime} 42^{\prime \prime}$ e $48^{\circ} 06^{\prime} 09^{\prime \prime}$ de longitude Oeste. 


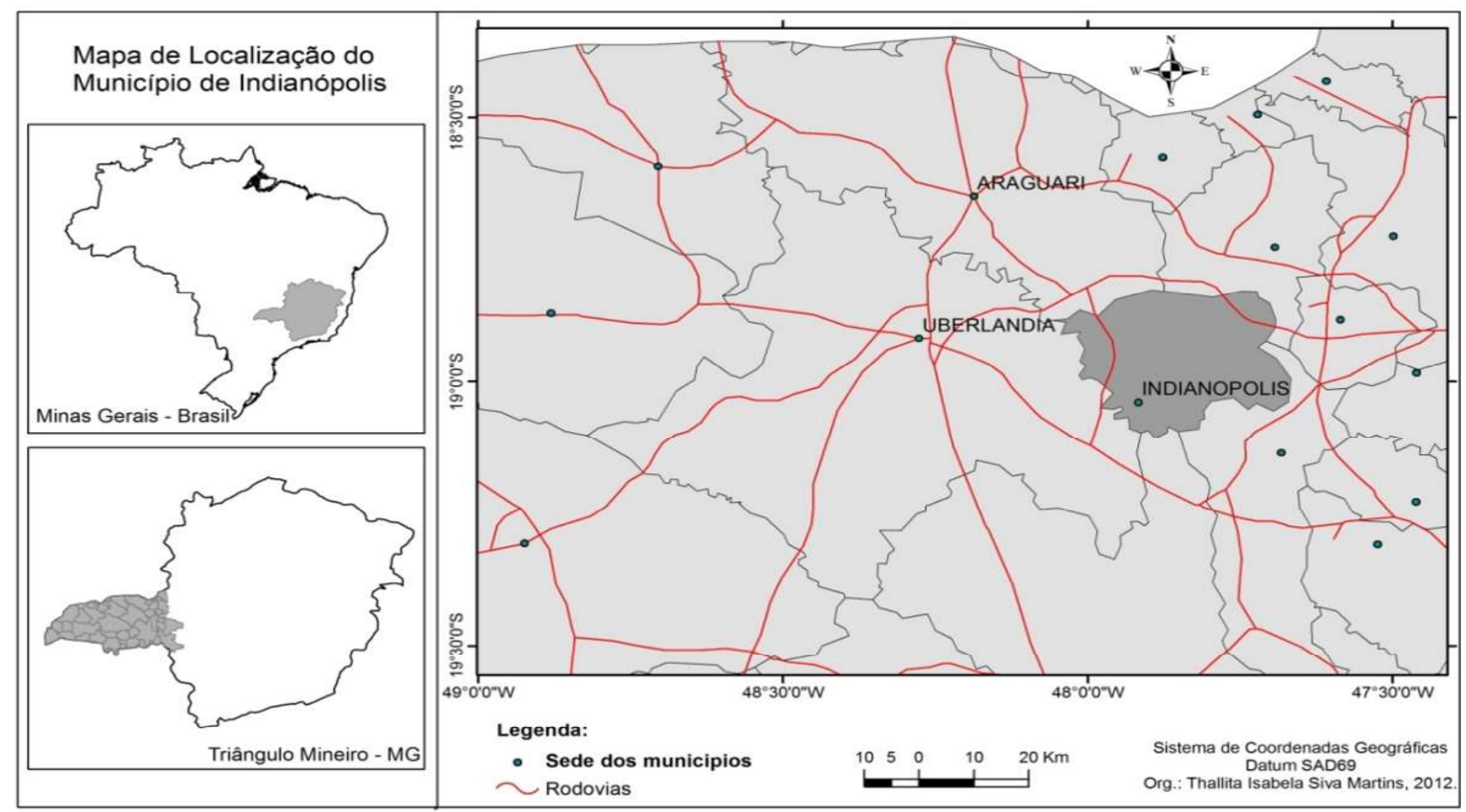

Figura 2 - Localização do município de Indianópolis, $M G$.

Este município apresenta um rico patrimônio geomorfológico, sendo as quedas d'água apenas uma pequena amostra dessa riqueza. A explicação para isso está associada aos aspectos geológico-geomorfológicos da região onde está inserida: Bacia Sedimentar do Paraná. Indianópolis se situa na porção nordeste desta bacia, apresentando rochas vulcano-sedimentares que se assentam de forma discordante sobre rochas do pré-Cambriano do Grupo Araxá e recobrindo as rochas mais antigas e localizadas nas partes superiores do relevo encontra-se a Cobertura Cenozoica (Bento e Rodrigues, 2011). No entanto, são os basaltos da Formação Serra Geral o representante litológico de maior expressão no município e que, inclusive, servem de substrato para os cursos d'água direcionando o sistema de drenagem, formação e evolução das quedas d'água.

A avaliação do potencial geoturístico das quedas d'água foi realizada em duas etapas. Inicialmente, em gabinete, foi analisada a obra "Potencial geoturístico das quedas d'água de Indianópolis", que traz um estudo detalhado das quedas. Foram examinados três critérios, a saber: $i$ - acessibilidade, $i i$ - diversidade litoestratigráfica e iii- estética. Os critérios escolhidos foram baseados no objetivo do trabalho que é a seleção das quedas d'água com maior potencial geoturístico, nesse sentido, privilegiaram-se aspectos condizentes com isso.
A composição litoestratigráfica foi um dos critérios de apreciação, por intermédio dela vislumbra-se o valor científico da geodiversidade, sendo possível explicar os processos de evolução geológica regional observando tal composição. Levou-se em consideração também, a acessibilidade e a estética das cachoeiras, aspectos relevantes quando da implantação da atividade turística. A partir desta avaliação foram selecionadas três quedas: Saltinho Chapadinho, Salto do Mirandão e Saltinho Santo Antônio.

Num segundo momento, em campo, foi efetuada a avaliação quantitativa das quedas pré-selecionadas a partir do preenchimento de uma ficha. Relevante ressaltar que, o preenchimento de fichas numéricas para a avaliação do patrimônio objetiva atenuar a subjetividade nos resultados, mas para que haja um maior aproveitamento e visão integrada de todos os aspectos é interessante que seja preenchida por uma equipe multidisciplinar, possibilitando um olhar mais diverso dos aspectos selecionados. No estudo em questão, foi analisada por dois geógrafos, uma bióloga, um jornalista e duas advogadas, ambos discentes e uma docente da disciplina "TÓPICOS ESPECIAIS III - Geodiversidade e Geoconservação", ministrada no segundo semestre de 2015 no Programa de Pós-graduação em Geografia do Pontal (FACIP-UFU), sendo, inclusive, um dos enca- 
minhamentos proporcionados pela mesma.

$\mathrm{Na}$ referida ficha, tendo em vista o propósito de seleção da queda de maior potencial geoturístico, privilegiou-se dois valores: científico e turístico (Figura 3). O critério do Valor Científico traz os seguintes itens a serem avaliados, são eles: Representatividade dos Processos Geomorfológicos; Integridade; Variedade Geomorfológica; Diversidade; Raridade/Excepcionalidade e Potencial
Didático. Já o critério do Valor Turístico: Acessibilidade; Condições de Observação; Segurança; Relevância Cultural; Estética e Equipamentos. Partindo destes critérios foi conferida uma pontuação de 0 a 3 de acordo com as características especificadas em cada item avaliado. Através do preenchimento desta ficha foi possível eleger a queda d'água com maior potencial geoturístico, tal como será apresentado nos resultados a seguir.

\begin{tabular}{|c|c|c|c|c|c|c|}
\hline & Critério & Explicaçäo & $\mathbf{0}$ & 1 & 2 & 3 \\
\hline & $\begin{array}{l}\text { Representatividade dos } \\
\text { processos } \\
\text { geom orfológicos }\end{array}$ & $\begin{array}{l}\text { De processos passadose } \\
\text { ativos através de } \\
\text { caracteristicas que the } \\
\text { conferem destaque entre } \\
\text { geoformassemelhantes }\end{array}$ & $\begin{array}{l}\text { Pouco } \\
\text { representativo }\end{array}$ & $\begin{array}{l}\text { Com alguma } \\
\text { representativida } \\
\text { de }\end{array}$ & $\begin{array}{|lr|}\text { B om } & \text { ex emplo } \\
\text { do } & \text { processo } \\
\text { geom orf ológyc } \\
0\end{array}$ & $\begin{array}{lr} & \text { melhor } \\
\text { ex emplo } & \text { do } \\
\text { processo } & \end{array}$ \\
\hline & Integridade & 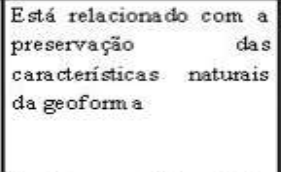 & \begin{tabular}{l|} 
Bastante \\
danificado por \\
ativida de \\
antrópica
\end{tabular} & $\begin{array}{lr}\text { Danificado } & \text { por } \\
\text { processos } & \\
\text { naturais, } & \text { mas } \\
\text { restrito } & \text { a } \\
\text { algumas } & \\
\text { caracteristicas }\end{array}$ & $\begin{array}{l}\text { Danificado mas } \\
\text { com } \\
\text { preservação } \\
\text { dos elem entos } \\
\text { geom orfológic } \\
\text { os }\end{array}$ & $\begin{array}{l}\text { Sem } \\
\text { deteriorização } \\
\text { visivel }\end{array}$ \\
\hline 总 & $\begin{array}{l}\text { V ariedade } \\
\text { geom orf ológica }\end{array}$ & $\begin{array}{l}\text { Reflete na diversidade } \\
\text { de formas e processos } \\
\text { existentes }\end{array}$ & \begin{tabular}{|l|}
$\begin{array}{l}\text { Apenas um } \\
\text { elemento } \\
\text { geom orfológe } \\
0\end{array}$ \\
\end{tabular} & \begin{tabular}{|l|} 
Duas \\
caracteristicas \\
geom orfológica \\
S, com interesse \\
cientifico
\end{tabular} & \begin{tabular}{|l|} 
Três \\
caracteristicas
\end{tabular} & Mais de três \\
\hline$\stackrel{\circ}{\circ}$ & Diversidade & $\begin{array}{l}\text { Apresenta outros tipos } \\
\text { de valores associados, } \\
\text { como o ecológico } \\
\text { (biodiversidade) }\end{array}$ & $\begin{array}{l}\text { Sem } \\
\text { associação }\end{array}$ & $\begin{array}{l}\text { Apenas } 1 \text { tipo } \\
\text { de interesse ou } \\
\text { tem ática }\end{array}$ & $\begin{array}{l}1-2 \text { tipos de } \\
\text { interesse }\end{array}$ & $\begin{array}{l}\text { Mais de } 3 \text { tipos } \\
\text { de interesse }\end{array}$ \\
\hline & $\begin{array}{l}\text { Raridadefex cepcionalid } \\
\text { ade }\end{array}$ & $\begin{array}{l}\text { Valorizou-se a raridade } \\
\text { da geoforma e da sua } \\
\text { dimensäo e/ou } \\
\text { expressão, no contexto } \\
\text { localou regional }\end{array}$ & $\begin{array}{l}\mid \hat{E} \text { uma das } \\
\text { várias } \\
\text { ocorrências }\end{array}$ & \begin{tabular}{|l|} 
É um exemplo \\
local
\end{tabular} & $\begin{array}{|lcc|}\text { É } & \text { o } & \text { único } \\
\text { ex em } & \text { plo local }\end{array}$ & $\begin{array}{l}\text { O único ou um } \\
\text { dos exemplos } \\
\text { raros a nivel } \\
\text { regional }\end{array}$ \\
\hline & Potencial didático & $\begin{array}{l}\text { Potencial para ilustrar } \\
\text { elementos ou processos, } \\
\text { com possibilidade de } \\
\text { uso do local por } \\
\text { estudantes }\end{array}$ & $\begin{array}{l}\text { Uso para um } \\
\text { público } \\
\text { especializado } \\
\text { (pesquisadores } \\
\text { D) }\end{array}$ & $\begin{array}{l}\text { Ilustra } \\
\text { conteúdos } \\
\text { apenas do } \\
\text { ensino médio }\end{array}$ & $\begin{array}{l}\text { Ilustra } \\
\text { conteúdos do } \\
\text { ensino médio e } \\
\text { fundam ental }\end{array}$ & $\begin{array}{l}\text { Ilustra conteúdos } \\
\text { para qualquer } \\
\text { escolaridade }\end{array}$ \\
\hline & Critério & \begin{tabular}{|l|} 
Explicação \\
\end{tabular} & $\begin{array}{l}\mathbf{0} \\
\end{array}$ & 1 & 2 & 3 \\
\hline & Acessibilida de & $\begin{array}{l}\text { Indicativo de } \\
\text { dificuldades de acesso } \\
\text { aolocal }\end{array}$ & Inacessive1 & \begin{tabular}{|l|} 
Acessivel por \\
trilha de mais \\
de 700 metros
\end{tabular} & $\begin{array}{l}\text { Acessive1 por } \\
\text { trilha de } 500- \\
700 \text { metros }\end{array}$ & $\begin{array}{l}\text { Acessivel por } \\
\text { tritha menor de } \\
500 \text { metros }\end{array}$ \\
\hline & $\begin{array}{l}\text { Condições } \\
\text { observaçäo }\end{array}$ & \begin{tabular}{|lr} 
Referente & à \\
possibilidade & de \\
observação do local
\end{tabular} & $\begin{array}{|lr|}\text { Presença } & \text { de } \\
\text { elementos } & \text { que } \\
\text { impedem } & \text { a } \\
\text { observação } & \end{array}$ & $\begin{array}{l}\text { Muito dificil, } \\
\text { visivel apenas } \\
\text { com ausilio de } \\
\text { equipam ento } \\
\text { (luz, corda...) }\end{array}$ & \begin{tabular}{|l|} 
Com \\
elem entos que \\
dificultam a \\
observação de \\
apenas alguns \\
conteúdos
\end{tabular} & $\begin{array}{l}\text { Facilm ente } \\
\text { observáve1 }\end{array}$ \\
\hline 异 & Segurança & $\begin{array}{|lll|}\text { Indicaçäo } & \text { de perigo } \\
\text { potencial } & \text { para } & \circ \\
\text { visitante } & & \end{array}$ & $\begin{array}{l}\text { Sem condições } \\
\text { mínimas de } \\
\text { segurança }\end{array}$ & \begin{tabular}{|l} 
Perigo elevado \\
(curso d'água, \\
muita \\
inclina çäo...)
\end{tabular} & \begin{tabular}{|l|} 
Perigo \\
reduzido \\
(apenas \\
necessidade de \\
precaução) \\
\end{tabular} & $\begin{array}{l}\text { Sem qualquer } \\
\text { perigo }\end{array}$ \\
\hline 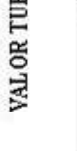 & Relevância cultural & $\begin{array}{|lr|}\text { Indicativo } & \text { de } \\
\text { associaçäo } & \text { com } \\
\text { elem entos } & \text { culturais } \\
\text { (eventos } & \text { religiosos ou } \\
\text { culturais) } & \end{array}$ & Ausente & - & - & $\begin{array}{l}\text { Vinculo direto } \\
\text { (religiosidade...) }\end{array}$ \\
\hline & Estética & $\begin{array}{l}\text { Prazer sentido no local } \\
\text { considerando } \\
\text { atratividade } \\
\text { paisagem e da } \\
\text { am biente, a presença da } \\
\text { água, vegetaçäo etc. }\end{array}$ & \begin{tabular}{|l|} 
Local \\
desconfortável \\
(presença de \\
lixo, por \\
exemplo)
\end{tabular} & $\begin{array}{l}\text { Local sem } \\
\text { atratividade }\end{array}$ & $\begin{array}{l}\text { Dotado de } \\
\text { algum } \\
\text { elemento } \\
\text { atraente }\end{array}$ & $\begin{array}{l}\text { Grande apelo } \\
\text { estético }\end{array}$ \\
\hline & Equipam entos & $\begin{array}{lr}\text { Existência } & \text { de } \\
\text { restaurantes } & \text { e } \\
\text { pousadashotéis, } & \\
\text { considerando } & \text { a } \\
\text { distância do local } & \end{array}$ & $\begin{array}{lrr}\text { Năo há } & \text { a } \\
\text { menos de } & 60 \\
\mathrm{~km} & & \end{array}$ & $\begin{array}{ll}\text { Entre } & 30-60 \\
\mathrm{~km}\end{array}$ & $\begin{array}{ll}\text { Entre } & 10-30 \\
\mathrm{~km} & \end{array}$ & $\begin{array}{l}\text { A menos de } 10 \\
\mathrm{~km}\end{array}$ \\
\hline
\end{tabular}

Figura 3 - Quadro com os critérios e parâmetros utilizados na avaliação das quedas d'água 


\section{Resultados e Discussão}

\section{Das características gerais}

A partir da avaliação qualitativa chegou-se, das vinte quedas d'água analisadas, a um resultado de três: Saltinho Chapadinho, Salto do Mirandão e Saltinho Santo Antônio (Figura 4).

A queda Saltinho Chapadinho (Figura 5) localiza-se no Córrego Chapadinho, a seis quilômetros da cidade de Indianópolis. Ela possui fácil acesso, devido à estrutura construída pelo proprietário que possibilita a chegada de veículo até a margem do curso d'água. Além disso, percebe-se nesta queda que o proprietário investiu em estrutura de quiosques e churrasqueira, privilegiando o lazer na área, além da pesca, nado e navegação no reservatório de Miranda, no Rio Araguari, que se encontra contíguo à queda. Em relação ao perfil litoestratigráfico, a queda Saltinho Chapadinho é formada, respectivamente, por gnaisse, arenito Botucatu e basalto e possui 16 metros de desnível topográfico, com formação de pequeno poço (Bento, 2010).

Dentre os valores científicos, o mais significativo trata-se do potencial didático, em razão da presença de três tipos de rochas em sua formação e a facilidade de acesso do local por estudantes e pesquisadores. No que tange ao valor turístico, destaca-se a facilidade de observação, uma vez que não há no local vegetação densa e a acessibilidade, em razão da inexistência de trilha. Frisa-se, ainda, a facilidade de hospedagem e alimentação, já que a queda localiza-se nas proximidades da cidade, porém, para a exploração turística ainda carece de melhorias, tais como sinalização turística, por exemplo.

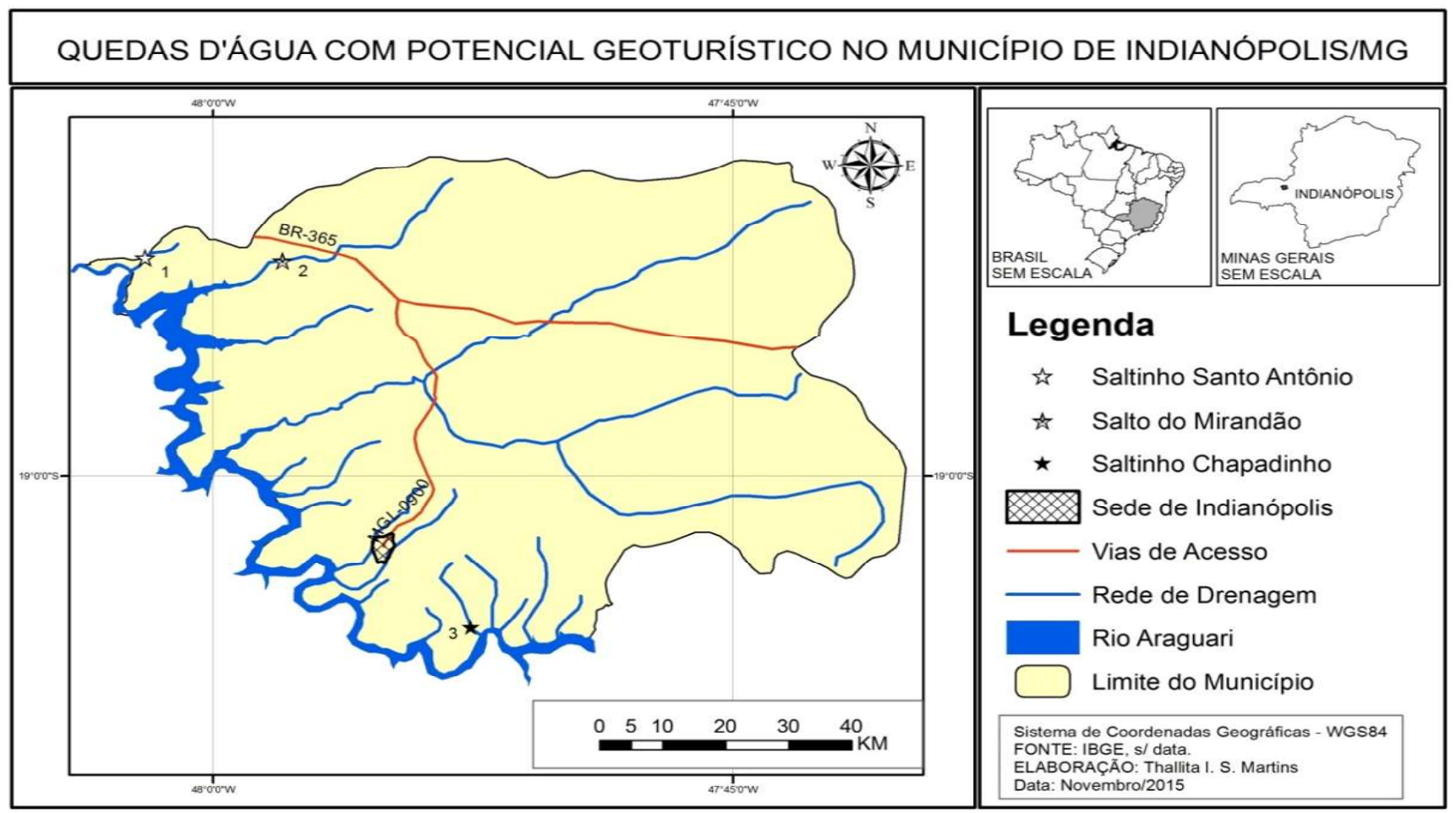

Figura 4 - Localização das quedas d'água analisadas

Por sua vez, a queda Salto do Mirandão (Figura 6) localiza-se no Córrego Boa Vista, a vinte e sete quilômetros da cidade de Indianópolis, com uma trilha de seiscentos e quarenta metros, de difícil acesso e muita inclinação em vários pontos. É a segunda maior queda do município, com um total de cinquenta e dois metros e possui em sua formação litoestratigráfica o gnaisse, $o$ arenito Botucatu e o basalto, facilmente identificáveis. O poço formado ao final da queda é ideal para banho e o elevado desnível da queda favorece a prática de rapel (Bento, 2010).

A integridade da geoforma local e o potencial didádico sobressaíram na avaliação realizada do potencial científico da queda. Já quanto ao potencial turístico, destacam-se as condições favoráveis de observação e a beleza cênica e encantamento proporcionados pela paisagem local. Destaca-se ainda, como ponto negativo, a falta de segurança local para visitantes ao percorrerem a trilha. 
Bento L. C. M. et al.

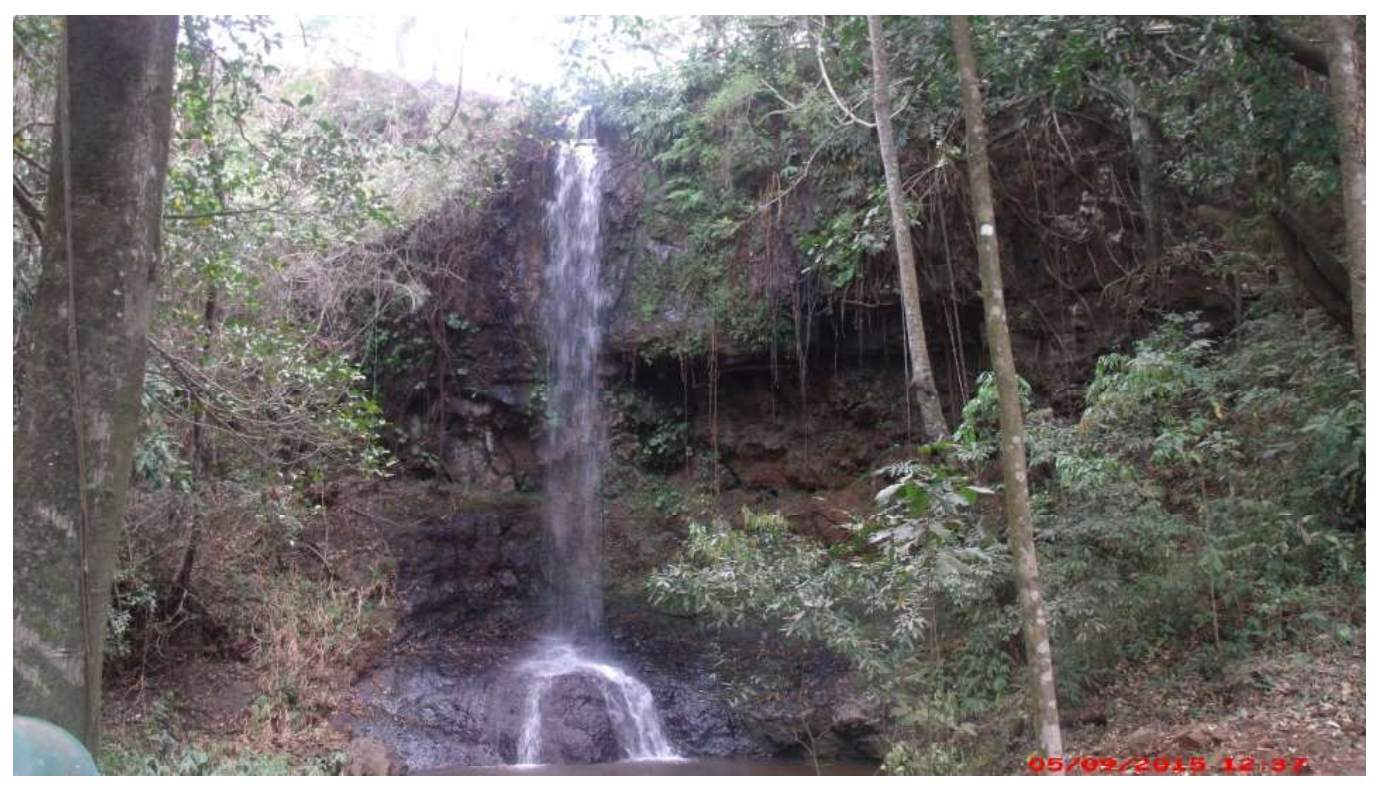

Figura 5 - Queda d'água Saltinho Chapadinho

Autor: Souza, 2015.

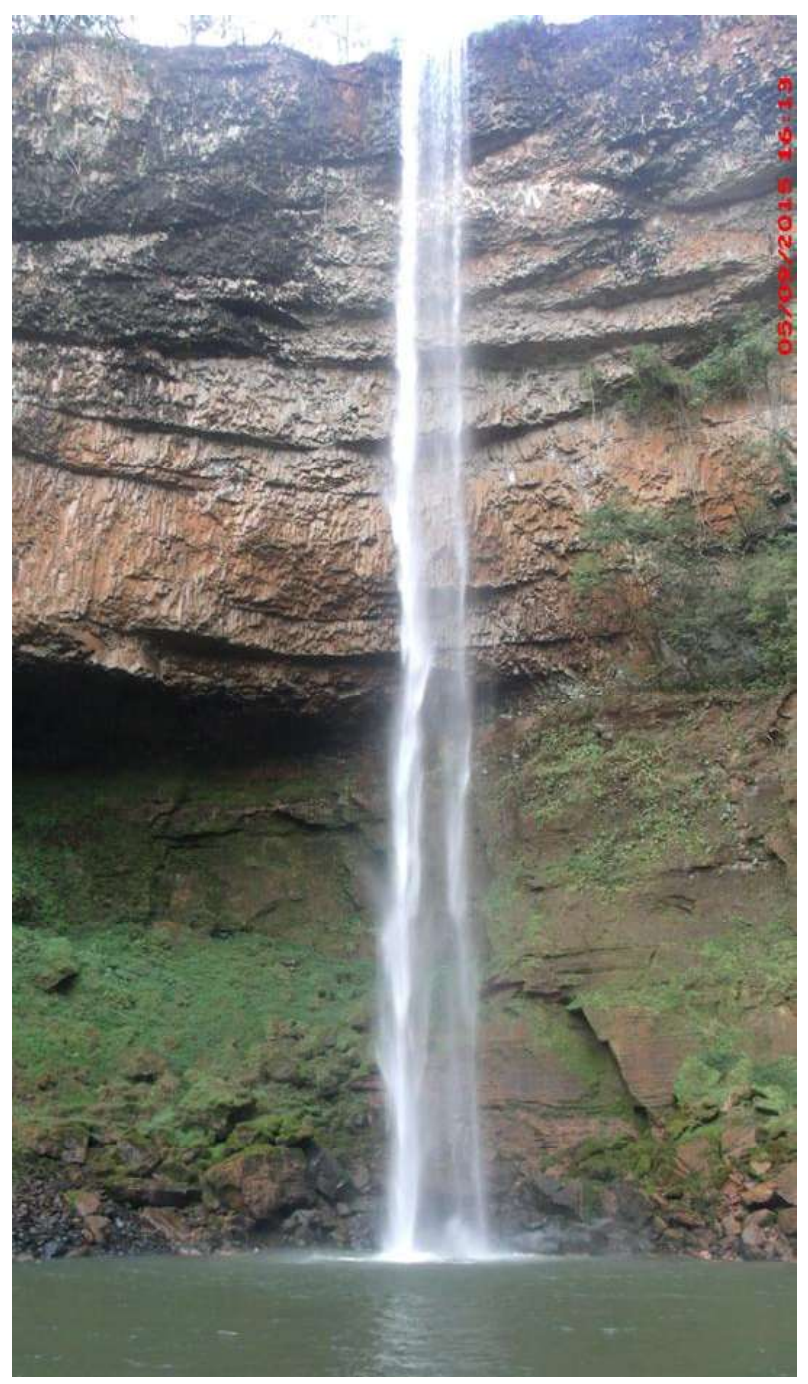

Figura 6 - Queda d'água Salto do Mirandão

Autor: Souza, 2015. 
A queda Saltinho Santo Antônio (Figura 7) situa-se no Córrego Santo Antônio, nas proximidades do Rio Araguari, a cinquenta e um quilômetros da cidade de Indianópolis. A trilha de acesso à queda é de duzentos metros, sem maiores dificuldades. Em sua formação encontra-se igualmente o gnaisse, o arenito Botucatu e o basalto. A queda Saltinho Santo Antônio possui 19,5 metros de altura, com formação de poço muito frequentado para banho (Bento, 2010).

Dentre suas características de cunho científico, destaca-se a diversidade local, pois além da geoforma, o valor ecológico encontra-se presente através da bio- diversidade no entorno da queda e durante o percurso da trilha, inclusive, localmente, essa queda é conhecida como Cachoeira dos Macacos pela presença desses animais. Nesta mesma linha, evidenciou-se o potencial didático por bem ilustrar a formação litoestratigráfica e os processos de intemperismo. No que tange ao valor turístico, sobressaíram a acessibilidade, as boas condições de observação e a relevância cultural, em razão do local possuir uso religioso pela comunidade, com presença de imagens, velas e oferendas a divindades relacionadas à água.

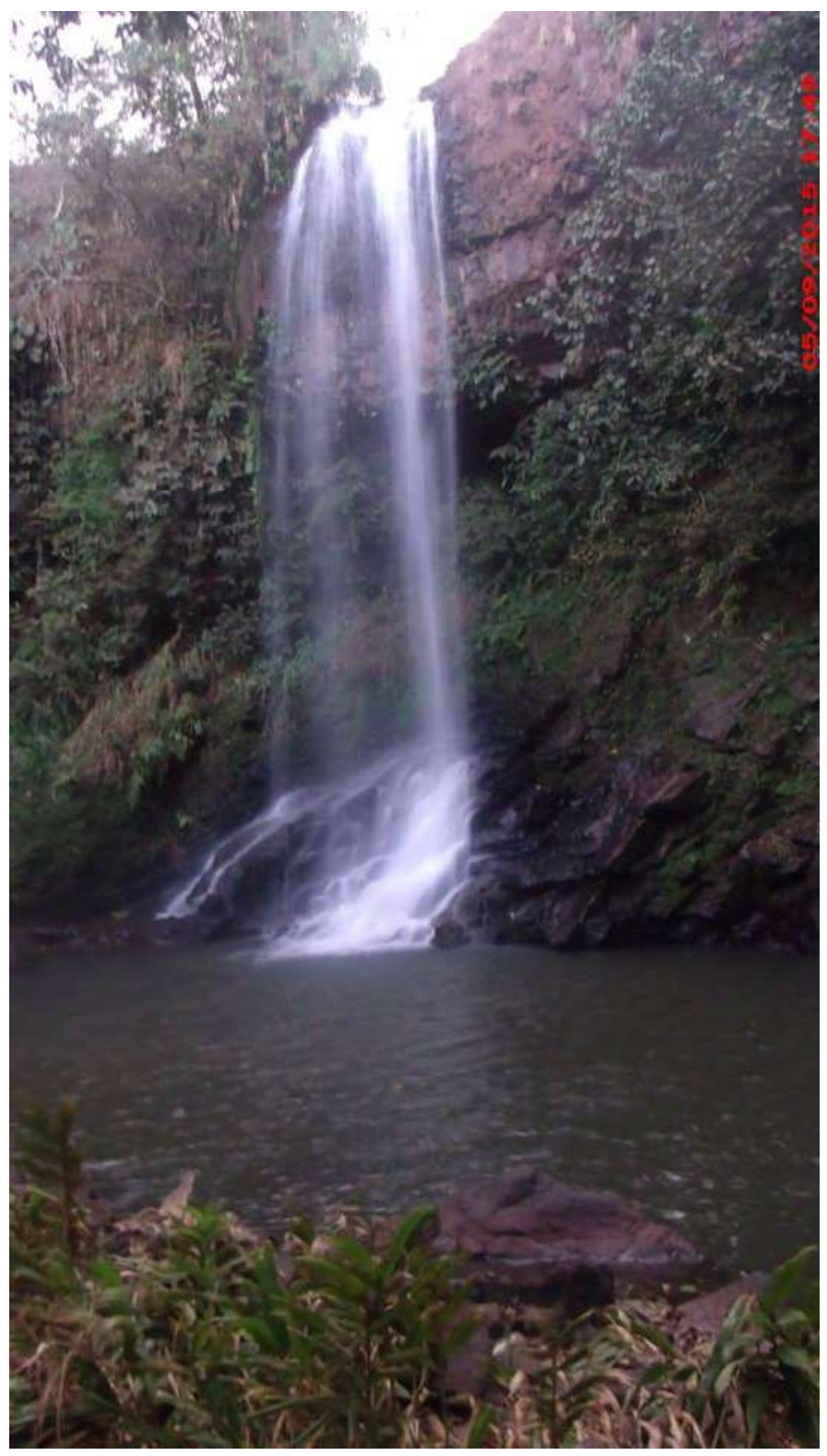

Figura 7 - Queda d'água Saltinho Santo Antônio

Autor: Souza, 2015. 


\section{Das especificidades}

Na Tabela1 são apresentados os resultados obtidos após a avaliação quantitativa de cada queda, em relação aos valores científicos e turísticos, de forma individualizada após a tabulação de cada avaliador, com a somatória ao final, indicando a queda d'água com maior potencial geoturístico do município de Indianópolis.

Tabela 1: Quantificação dos valores científicos e turísticos das quedas d'água do município de Indianópolis - com grifo na queda de maior potencial geoturístico

\begin{tabular}{|c|c|c|c|}
\hline & Saltinho Chapadinho & Salto do Mirandão & $\begin{array}{c}\text { Saltinho Santo } \\
\text { Antônio }\end{array}$ \\
\hline \multicolumn{4}{|l|}{ Valor Científico } \\
\hline $\begin{array}{l}\text { Representatividade dos } \\
\text { processos morfológicos }\end{array}$ & 1,6 & 2 & 2 \\
\hline Integridade & 2,0 & 2,2 & 1,2 \\
\hline Variedade Geomorfológica & 1,8 & 2,2 & 2 \\
\hline Diversidade & 2 & 2,2 & 2,6 \\
\hline Raridade/Excepcionalidade & 0 & 1 & 0,2 \\
\hline Potencial Didático & 2,8 & 2,4 & 3 \\
\hline \multicolumn{4}{|l|}{ Valor Turístico } \\
\hline Acessibilidade & 3 & 1,2 & 2,6 \\
\hline Condições de Observação & 2,8 & 3 & 3 \\
\hline Segurança & 2,4 & 1,6 & 2,4 \\
\hline Relevância Cultural & 0 & 0 & 2,4 \\
\hline Estética & 1,8 & 3 & 2,2 \\
\hline Equipamentos & 2,4 & 1,8 & 1,6 \\
\hline TOTAL & 22,6 & 22,6 & 25,2 \\
\hline
\end{tabular}

Assim, verificando os resultados apresentados, apreende-se que a queda d'água Saltinho Santo Antônio é a que apresenta uma maior somatória dos valores científicos e turísticos que foram utilizados para essa quantificação. Tal fato se deu, em especial, por dois aspectos, a saber: $i$ - elevado potencial didático da queda, consubstanciado pela presença de três tipos de rocha bem definidas e de fácil visualização que permitem, em linhas gerais, abordar quatro temas-chave principais (evolução geológica do planeta Terra, ciclo das rochas, estratificação e intemperismo), com múltiplas possibilidades de desdobramentos e aprofundamento conforme o perfil do público e $i i$ - facilidade de acesso ao local, que se encontra bem próximo da BR 365 , com pequeno trecho de estrada de terra e trilha de acesso de curta extensão e pouca inclinação, sem exigir grande preparo físico de seus visitantes, o que justifica a presença de muitos banhistas no local.

Além disso, a queda d'água Saltinho de Santo Antônio foi a única a apresentar valor turístico em relação à relevância cultural, tornando-se um diferencial para a análise do potencial turístico dessa queda, que atrai visitantes que vão ao local professar sua fé. Muitas religiões, principalmente, as afro-brasileiras, usam a natureza como um altar de adoração e os elementos naturais como oferendas e cada elemento natural remete a um fragmento da energia criadora das divindades. No livro "Espaço e cultura na Religiosidade afro-brasileira", Portuguez (2015) faz uma reflexão aprofundada sobre o sagrado e suas relações com a natureza nas religiões afro-brasileiras. Segundo ele, os praticantes da religiosidade afro-brasileira utilizam diversos elementos da natureza que remete ao sagrado, no caso dos elementos associados à Geodiversidade ele cita as formas de relevo, cavernas, praias, ilhas, nascentes e as cachoeiras. Em especial sobre a água, ela congrega diversas deusas femininas como Oxum (Deusa do rio de mesmo nome na Nigéria), Yemanjá (Deusa do rio Ogum e compartilha o domínio das águas salgadas com Olokun e outros(as) Orixás), Oyá (Deusa do rio Níger), Iyewá (Deusa do rio de mesmo nome na porção central da Nigéria), entre outros exemplos. Os praticantes dessas religiões têm, portanto, por alguns elementos da Geodiversidade, como as quedas d'água, um grande respeito e sentimento de pertencimento, segundo eles, “[...] a natureza não está "fora de nós" porque em nossos corpos físicos há fragmentos das muitas matérias criadas pelos (as) Orixás" (p. 90-91), evidenciando o Valor Cultural dessa geoforma pelos praticantes dessas religiões.

No quesito Integridade, no Saltinho Santo Antônio, os números também apresentam um valor relativamente baixo, em comparação com as demais quedas d'água. Esse fato pode ser atribuído a uma maior circu- 
lação de pessoas naquele local e à falta de mecanismos para conservação da mesma, existindo algumas marcas de degradação como focos de descarte de lixo e erosão, por exemplo.

Isto posto, a queda d'água Saltinho de Santo Antônio é a que apresenta maior potencial geoturístico dentre as quedas avaliadas no município de Indianópolis, devido, particularmente, aos seguintes fatores: diversidade, acessibilidade, segurança, boas condições de observação e relevância religiosa.

\section{Das possibilidades}

Através da visualização dos três tipos de rochas no perfil da queda do Saltinho Santo Antônio (Figura 8) é possível fazer um rápido apanhado da evolução geológica e geomorfológica da área.

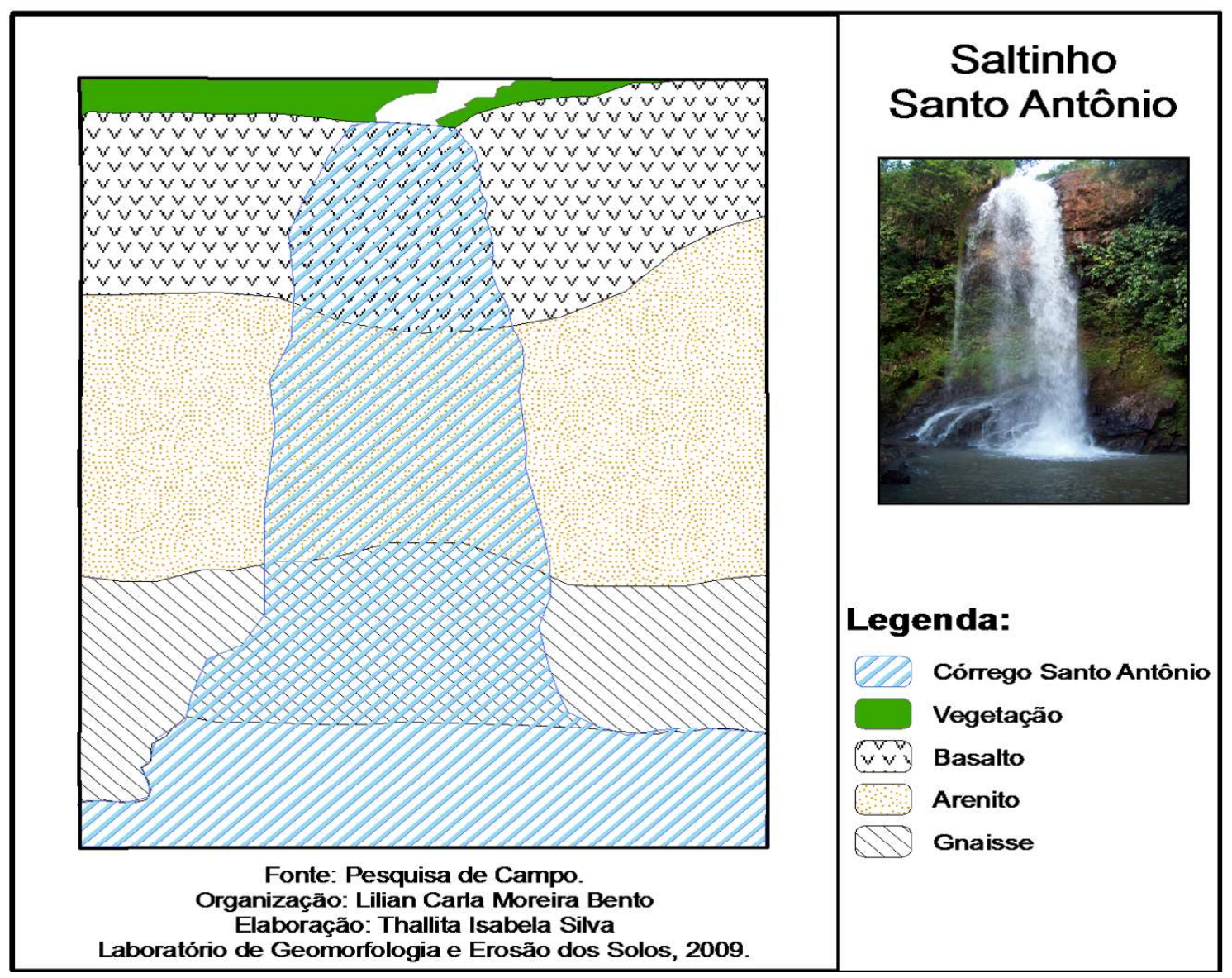

Figura 8 - Perfil litoestratigráfico do Saltinho Santo Antônio

Essas rochas compreendem parte da história geológica do planeta Terra, desde o Proterozoico até o Mesozoico, eras associadas, respectivamente, ao Grupo Araxá (gnaisses) e Grupo São Bento (arenitos e basaltos), pois as rochas e também os fósseis são os registros, os testemunhos de todos os processos e/ou acontecimentos do nosso planeta. Segundo Bento e Rodrigues (2010) o gnaisse encontrado na parte inferior do perfil da queda foi formado no pré-Cambriano, era que corresponde a $80 \%$ da história da Terra, desde a formação do planeta até o surgimento das primeiras formas de vida, como as bactérias, os fungos e as algas. É um tipo de rocha metamórfica que, em conjunto com as rochas ígneas, constituem as principais litologias encontradas nessa fase e aparece junto às margens do rio Araguari e em trechos inferiores dos seus afluentes, tais como o que encontramos na base do Saltinho Santo Antônio.

Já os arenitos da Formação Botucatu surgiram entre o Triássico e o Jurássico (Mesozoico), época em que o clima foi ficando cada vez mais seco e quente, propiciando a formação de grandes desertos arenosos. Silva (2004, p. 54) argumenta que nesta época os ventos moveram grande parte das areias destes desertos, gerando "[...] depósitos sedimentares compostos por arenitos avermelhados de granulação fina a média com estratificações cruzadas de médio a grande porte", vindo a formar 
a Formação Botucatu. Em termos de biodiversidade, o Triássico corresponde ao período de surgimento dos primeiros dinossauros, mamíferos ovíparos e árvores de grande porte, as coníferas. E, no Jurássico, começa a haver a separação da África e da América do Sul e os répteis marinhos foram as maiores formas de vida encontradas. Além disso, foi o momento em que surgiram os primeiros pássaros e plantas com flores (Bento e Rodrigues, 2010).

Os autores supracitados explicam que, entre o Jurássico e o Cretáceo, surgiu a Formação Serra Geral, época em que ainda predominavam as condições desérticas, correspondendo ao vulcanismo fissural passivo devido a separação de continentes, quando "[...] as lavas, muito fluidas, subiam por fissuras, grandes fendas ou falhas menores, em rápida intrusão, escoamento e represamento nos terrenos arenosos ou inter-dunas" (Silva, 2004, p. 55). O Cretáceo corresponde ao período em que houve o desaparecimento dos dinossauros, entre outras espécies animais e vegetais e, em contrapartida, surgem os mamíferos placentários (Bento e Rodrigues, 2010).

Não só as rochas contam uma história, como elas são o palco aonde diversos processos naturais vêm ocorrendo ao longo do tempo geológico, permitindo abordar temas como as propriedades geomorfológicas das rochas e sua relação com a evolução da queda. Nesse sentido, Penteado (1983) argumenta que as propriedades básicas das rochas, tais como grau de coesão, permeabilidade e de plasticidade, grau de maciez e tamanho dos grãos, grau de maciez e tamanho dos grãos influem no modo de escoamento superficial, na desagregação mecânica e na composição química, sendo aspectos fundamentais no entendimento de como uma queda d'água evolui.

Além de evidenciar o Saltinho Santo Antônio pelos valores de sua geodiversidade é possível, ainda, destacar seu valor ecológico. O município de Indianópolis está inserido no Bioma Cerrado e, devido às diferenças de solo, relevo e topografia, há variados tipos de fisionomias de vegetais, tais como formações abertas e formações fechadas. Ribeiro e Walter (1998) consideram que as formações florestais do Cerrado englobam os tipos de vegetação com predominância de espécies arbóreas e formação de dossel, sendo as matas Ciliar e a de Galeria fisionomias associadas a cursos de água, como no caso das quedas d'água. De acordo com Kuntschik, Eduarte e Uehara (2014), a importância ecológica dessas matas está associada, principalmente, aos serviços ambientais de: - efeito de filtro e tampão: cola- boram para a qualidade quantidade de água, ao reterem excesso de sedimentos; evitam deslizamentos de terra e assoreamento dos rios; - proteção de ribanceiras, pela rede formada pelas raízes; - atuação como corredores ecológicos; - fixação do gás carbônico, sendo, também, locais de altíssima diversidade biológica, usados como refúgio e fonte de alimentos para diversas espécies de animais. Essas áreas são áreas importantes, portanto, do ponto de vista biogeográfico, pois criam condições ambientais específicas, "sendo um ambiente muito propício ao surgimento de espécies endêmicas de plantas e animais, tudo isto em função da umidade do ar, no solo e nas paredes rochosas" (Rodrigues e Oliveira, 2007, p. 28) e, atentar a esse valor ecológico, em conjunto com os valores da Geodiversidade, permite uma visão integrada dos aspectos bióticos e abióticos da natureza e, sendo assim, mais condizente com a dinâmica ambiental.

\section{Considerações e Recomendações}

Em vista dos apontamentos realizados neste trabalho, ressaltamos a importância das metodologias de avaliação do patrimônio geológico no contexto científico como necessidade preliminar para formulação de ações dedicadas a conservação dos aspectos abióticos em áreas tomadas como patrimônio. A partir delas é possível identificar os aspectos relevantes da área e os limites de conservação da qual se pretende apoiar tanto o patrimônio, quanto a atividade de geoturismo, como no estudo de caso do município de Indianópolis. Nesse sentido, as quedas d'água sobressaem na região em função do fluxo intensivo de pessoas que as procuram para lazer e para cultuar ou professar sua fé, compondo uma atividade de grande interesse local.

As metodologias que favorecem a apreciação científica, educacional e o quadro estético da paisagem, contribuem para aspectos de proteção tal como apontados aqui como norteadores das metodologias de avaliação em razão da variação histórica pela qual o objeto (quedas d'água) estudado se insere e das possibilidades de alternância das quais o contexto social os (re) significa. Desta maneira, torna-se relevante observar o caráter cultural proporcionado pela área que promove a atração turística desempenhada no local, assim como os valores científicos e educacionais que oferecem ao conteúdo contemplado em vista da necessidade e da importância de sua conservação.

Por meio da adaptação destas metodologias para 
o estudo em questão, chegou-se a conclusão de que a queda d'água Saltinho Santo Antonio é a que apresenta maior potencial geoturístico. É preciso, desse modo, reconhecer que, tal como se encontra hoje, é apenas um potencial e não um produto turístico. Isso equivale a dizer que é um espaço que se desenvolve à medida em que o interesse social se manifesta através da visitação, e que, por isso, faz-se necessário a formatação de formas de políticas públicas que estabeleçam possibilidades de acesso e estrutura para comportar o movimento de visitação e, ao mesmo tempo, de conservação dos aspectos inerentes as possibilidades de geoturismo no local. A necessidade de um planejamento turístico se impõe no sentido de minimizar e planejar impactos decorrentes do uso dos aspectos funcionais dessa potencialidade. Assim, a trilha de acesso, o material rochoso de interesse educacional e científico, tal como a beleza cênica da paisagem, tornam-se atributos que merecem ser relevados no contexto geral do local e organizados de maneira concisa pela administração pública responsável. Desse modo, cria-se a oportunidade de dinamizar a economia local sem comprometer a condição ambiental da qual o potencial se cerca.

Outra possibilidade de conservação da queda é a elaboração de projetos de interpretação ambiental no âmbito do geoturismo e, também do ecoturismo, que desencadeiam possibilidades de entendimento e de valorização destes locais, tanto no viés da biodiversidade como da geodiversidade, permitindo uma visão integrada do meio ambiente. A identificação, o reconhecimento e a indicação desse potencial contribui para oferecer o conhecimento e os saberes locais aos visitantes interessados, mas, principalmente, para a multiplicação desse conhecimento que se enraíza na articulação entre os valores da população e de seu espaço, da ciência que alicerça o potencial e da política que media e oferece ao público um retorno do entendimento acerca do conjunto formado.

\section{Agradecimentos}

À Coordenação de Aperfeiçoamento de Pessoal de Nível Superior (CAPES) pela bolsa de pós doutorado $\mathrm{n}^{\circ}$ processo 1527165 cedida a Lilian Carla Moreira Bento.

\section{Referências Bibliográficas}

ARAÚJO, E. L. da S. Geoturismo: conceptualização, implementação e exemplo de aplicação ao Vale do Rio Douro no Setor Porto-Pinhão. 2005. Dissertação (Mestrado em Ciências do Ambiente). Escola de Ciências, Universidade do Minho, Minho, 2005. 219 p.

BENTO, L. C. M. Potencial geoturístico das quedas d'água de Indianópolis. 2010. Dissertação (Mestrado em Geografia). Instituto de Geografia, Universidade Federal de Uberlândia, Uberlândia, 2010. 142 p. Disponível em: http://www.bdtd.ufu.br/ tde_arquivos/15/TDE-2010-05-10T164254Z-1970/Publico/307O. pdf. Acesso em: 06 nov. 2016.

BENTO, L. C. M.; RODRIGUES, S. C. Geodiversidade e Potencial Geoturístico do Salto de Furnas - Indianópolis-MG. RA'EGA - O Espaço geográfico em Análise, Curitiba, v. 21, p. 272-297, 2011. Disponível em: http://ojs.c3sl.ufpr.br/ojs2/index.php/raega/issue/ view/1153. Acesso em: 10 nov. 2016

BENTO, L. C. M.; RODRIGUES, S. C. Gênese e aspectos litoestratigráficos do Saltinho Santo Antônio/Indianópolis-MG: refletindo sobre seu potencial geoturístico. Revista de Geografia, v. 3, p. 127-140, 2010. Disponível em: <http://www.revista.ufpe. br/revistageografia/index.php/revista/article/view/241/281>.Acesso em: 12 set. 2016

BORBA, A. W. de. Geodiversidade e geopatrimônio como bases para estratégias de geoconservação: conceitos, abordagens, métodos de avaliação e aplicabilidade no contexto do Rio Grande do Sul. Pesquisas em Geociências, Porto Alegre, v. 38, n. 1, p. 3 - 14, jan./abr. 2011.

BRILHA, J. Patrimônio geológico e geoconservação - a conservação da natureza na sua vertente geológica. Braga: Palimage, 2005.

BRILHA, J. Geoconservation and protected áreas. Environmental conservation, v. 29, n. 3, p. 273-276, 2002. [mensagem pessoal]. Mensagem recebida por <liliancmb@yahoo.com.br> em 30 ago. 2012.

DOWLING, R. K. Geotourism's global growth. Geoheritage, v. 3., p. 1-13, 2011. Disponível em: <http://www.springer.com>. Acesso em: 2 mar. 2012

EVAngelista, V. K.; TRAVASSOS, L. E. P. Patrimônio Geomorfológico do Parque Estadual do Sumidouro. Belo Horizonte: PUC Minas, 2014. 139 p.

FONSECA, M. H. A. de. Estabelecimento de critérios e parâmetros para a valoração do património geológico português - aplicação prática ao património geológico do Parque Natural de Sintra-cascais. 2009. Dissertação (Mestrado em Ordenamento do Território e Planejamento Ambiental). Faculdade de Ciências e Tecnologia, Universidade Nova de Lisboa, 2009. 166 p.

FORTE, J. P. Patrimônio geomorfológico da Unidade Territorial 
de Alvaiázere: inventariação, avaliação e valorização. 2008. Dissertação (Mestrado em Geografia). Departamento de Geografia, Universidade de Lisboa, Lisboa, 2008. 295 f.

GRAY, M. Geodiversity and Geoconservation: what, why, and how? Geodiversity \& Geoconservation, p. 4-12, 2005. Disponível em: <http://www.georgewright.org/223gray.pdf>. Acesso em:7 fev. 2012.

GRAY, M. Valuing geodiversty. Revista Geology today, v. 28, n. 1, p. 167-168, jun. 2011. [mensagem pessoal]. Mensagem recebida por<liliancmb@yahoo.com.br>em 30 ago. 2012.

GRAY, M. Geodiversity: valuing and conserving abiotic nature. Londres: John Wiley \& Sons Ltda, 2004. 434p.

KUNTSCHIK, D. P.; EDUARTE, M.; UEHARA, T. H. K. Matas ciliares. 2 ed. São Paulo: SMA, 2014. 82 p.

LIMA, F. F. de. Proposta metodológica para a inventariação do Patrimônio Geológico Brasileiro. 2008. Dissertação (Mestrado em Patrimônio Geológico e Geoconservação). Escola de Ciências, Universidade do Minho, Minho, 2008. 103 p.

LUZ NETTO, F. M. da. Identificação dos locais de interesse Geomorfológico do rio Claro- Triângulo Mineiro. 2015. Dissertação (Mestrado em Geografia). Instituto de Geografia, Universidade Federal de Uberlândia, Uberlândia, 2015. . 96 p.

NASCIMENTO, M. A.; RUCHKYS, U. A. de; MANTESSO NETO, V. Geodiversidade, geoconservação e geoturismo trinômio importante para a proteção do patrimônio geológico. São Paulo: Sociedade Brasileira de Geologia, 2008. 84p.

PENTEADO, M. Fundamentos de Geomorfologia. 3 ed. Rio de Janeiro: IBGE, 1983. 185 p.

PEREIRA, P.J. da S. Patrimônio geomorfológico: conceptualização, avaliação e divulgação. Aplicação ao Parque Natural de Montesinho. 2006. Tese (Doutorado em Ciências). Escola de Ciências, Universidade do Minho, Minho, 2006. 395 p.

PINTO, V.K. E.; TRAVASSOS, L. E. P. Inventariação, caracterização e proposta de valorização do patrimônio geomorfológico do Parque Estadual do Sumidouro, Minas Gerais. In: Congresso Brasileiro de Espeleologia, 32., 2013, Barreiras. Anais... Campinas: SBE, 2013, p. 23-30. Disponível: <http://www.cavernas.org.br/ anais32cbe/32cbe_023-030.pdf $>$. Acesso em: 05 nov. 2016.

PORTUGUEZ, A. P. Espaço e cultura na religiosidade afrobrasileira. Ituiutaba: Barlavento, 2015. 139 p.

REYNARD, E. Scientific research and tourist promotion of geomorphologica heritage. Geogr. Fis. Dinam. Quat., v. 31, p. 225-230, 2008. [mensagem pessoal]. Mensagem recebida por $<$ liliancmb@yahoo.com.br> em 30 ago. 2012.

RIBEIRO, J. F.; WALTER, B. M. T. (1998). Fitofisionomias do bioma Cerrado In: SANO, S.

M.; ALMEIDA, S. P. (ed.). Cerrado: ambiente e flora. Brasília, Embrapa Cerrados: p.87-166.

ROBINSON, E. Tourism in geological landscapes. Geology today, p. 151-153, jul./aug. 1998. [mensagem pessoal]. Mensagem recebida por<liliancmb@yahoo.com.br> em 30 ago. 2012.

RODRIGUES, J. de C. Património geológico no Parque Natural do Douro Internacional: caracterização, quantificação da relevância e estratégias de valorização dos geossítios. 2008. Dissertação (Mestrado em Património Geológico e Geoconservação). Escola de Ciências, Universidade do Minho, Minho, 2008. 205 p.

RODRIGUES, S. C.; OLIVEIRA, P. C. A. de. 2007. Programa de registro de patrimônio natural - Complexo Energético Amador Aguiar. Araguari: Zardo. 90 p.

SANTOS, E. M.; MARIANO, G.; NASCIMENTO, M. A. L. do. Geotouristic potential of waterfalls in igneous and metamorphic rocks: the case of the municipality of bonito, Pernambuco, northeast Brazil. Caderno de Geografia, v. 25, n. 23, p. 179-191, 2015.

SANTOS, F. M. dos. Caracterização geoambiental das cachoeiras do município de Guarulhos/SP: uma avaliação do seu potencial geoturístico. 2015. Dissertação (Mestrado em Análise Geoambiental), Universidade de Guarulhos, Guarulhos, 2015. 147 p.

SILVA, J. R. B. da. Contribuições da geologia para o desenvolvimento sustentável do turismo no município da Estância Turística de Paraguaçu Paulista (SP). 2004. Dissertação (Mestrado em Geociências e Meio Ambiente). Instituto de Geociências e Ciências Exatas, Universidade Estadual Paulista, Rio Claro, 2004. 118 p.

SILVA, C. R. da et al. (2009). Começo de tudo. In: SILVA, C. R. da (Ed.). Geodiversidade do Brasil - conhecer o passado para entender o presente e prever o futuro. [S.1]: CPRM: p. $11-20$.

SCHOBBENHAUS, C.; SILVA, C.R. 2012. Geoparques do Brasil: propostas. CPRM - Serviço Geológico do Brasil, 745p.

VIEIRA, A.; CUNHA, L. Patrimônio geomorfológico - tentativa de sistematização. 2004. Disponível em: <http://www.geografia. uminho.pt>. Acesso em: 10 mar. 2016. 